\title{
Pregnancy rate evaluation in lactating and non-lactating Nelore cows subjected to fixed-time artificial insemination using injectable progesterone
}

\author{
Avaliação da taxa de prenhez de vacas Nelore lactantes e não \\ lactantes submetidas à inseminação artificial em tempo-fixo a base \\ de progesterona injetável
}

\author{
Jefferson Tadeu Campos ${ }^{1}$; Fábio Morotti ${ }^{1}$; Larissa Zamparone Bergamo ${ }^{2}$; \\ Camila Bortoliero Costa ${ }^{2}$; Marcelo Marcondes Seneda ${ }^{3 *}$
}

\begin{abstract}
Most fixed-time artificial insemination (FTAI) protocols utilize progesterone (P4) as a hormonal source to achieve synchronization of estrus in cattle. The use of an injectable P4 source to control estrus would be an interesting pharmacological strategy owing to the practicality of parenteral application. However, the effects of injectable P4 on estrus cycle control in cattle remain poorly studied. In particular, no existing studies have investigated the effect of injectable P4 on the fertility of cows subjected to FTAI. The aim of this study was to evaluate the pregnancy rate of lactating and non-lactating Nelore cows subjected to FTAI with injectable P4. Of the 422 non-lactating cows in this study, 162 (38.3\%) became pregnant by 60 days post-FTAI. In the lactating group $(n=516), 166(32.1 \%)$ were pregnant by 60 days after treatment with injectable $\mathrm{P} 4$. The proportions of lactating and non-lactating cows becoming pregnant were compared using the chi-square test, adopting a significance level of $\mathrm{P}<0.05$. It was found that the pregnancy rate of the cows subjected to FTAI with injectable P4 was influenced by lactation status. Lactating cows had lower reproductive performance, possibly because of their higher nutritional requirements. However, the use of injectable $\mathrm{P} 4$ shows promising results and may prove to be a useful strategy in large-scale livestock production.
\end{abstract}

Key words: Injectable progesterone. Lactating cow. Non-lactating cows Synchronization of ovulation. Pregnancy rate.

\section{Resumo}

Em bovinos a maioria dos protocolos de inseminação artificial em tempo-fixo (IATF) utiliza a progesterona (P4) como base hormonal para a sincronização do estro. A utilização de uma fonte de P4 injetável para este controle do ciclo estral poderia ser uma estratégia farmacológica interessante, devido à praticidade de uma aplicação parenteral. $\mathrm{O}$ efeito da $\mathrm{P} 4$ injetável no controle da dinâmica folicular em bovinos tem sido pouco estudado, e até o momento, não há estudos que investigaram o efeito da P4 injetável na fertilidade de vacas submetidas à IATF. O objetivo do presente estudo foi avaliar a taxa de prenhez de vacas Nelore em lactação e não lactantes, submetidas a um protocolo de IATF a base de

1 Discentes do Curso de Doutorado, Programa de Pós-Graduação em Ciência Animal, Universidade Estadual de Londrina, UEL, Londrina, PR, Brasil. E-mail: jcampos007@hotmail.com; fabiomorotti@hotmail.com.

${ }^{2}$ Discentes do Curso de Mestrado, Programa de Pós-Graduação em Ciência Animal, UEL, Londrina, PR, Brasil. E-mail: larissabergamo1@hotmail.com; cbortoliero@gmail.com.

${ }^{3}$ Prof. Dr., Departamento de Clínicas Veterinárias, Laboratório de Reprodução Animal, Centro de Ciências Agrárias, UEL, Londrina, PR, Brasil. E-mail: mseneda@uel.br

* Author for correspondence 
P4 injetável. Neste estudo, foi demonstrado que das 422 vacas não lactantes, 162 (38,3\%) tornaramse gestantes 60 dias após a IATF. No lote de vacas lactantes $(\mathrm{N}=516), 166(32,1 \%)$ estavam prenhes após a sincronização com protocolo hormonal à base de $\mathrm{P} 4$ injetável. A proporção de vacas gestantes lactantes e não lactantes foram comparadas pelo teste do Qui-Quadrado adotando nível de significância quando $\mathrm{p}<0,05$. A taxa de prenhez de vacas submetidas à IATF com P4 injetável foi influenciada pelo status lactacional. Vacas lactantes apresentaram menor desempenho reprodutivo, possivelmente devido a maior exigência nutricional. No entanto, o uso da P4 injetável mostrou resultados promissores, podendo ser uma estratégia interessante em rebanhos em larga escala.

Palavras-chave: Progesterona Injetável. Vaca lactante. Vaca não lactante. Sincronização da ovulação. Taxa de prenhez.

\section{Introduction}

Improvements in reproductive efficiency are strategically important in managing cattle productivity. Of several such strategies that have recently been employed in the optimization of cattle reproduction, synchronization of ovulation stands out as one of the most notable techniques, used to optimize the reproductive management in cattle, owing to improvements in pregnancy rate and genetic gain. The benefits of artificial insemination (AI) are already well known and this technique certainly provides several improvements in the herd. However, one of the main advantages of AI is directly linked to the genetic improvement of livestock and obtaining animals with greater potential for production and reproduction (LAMB et al., 2014).

In an ovulation synchronization program in beef cattle, approximately $40-60 \%$ of cows subjected to fixed-time artificial insemination (FTAI) became pregnant after a single insemination procedure. However, this pregnancy rate may vary owing to variability between individual animals and animal categories, as well as in factors such as sanitary and nutritional management, body condition scores (BCS), the postpartum period and hormonal treatments (BARUSELLI et al., 2002, 2004).

Most current FTAI protocols in cattle use progesterone (P4) as their hormonal basis for synchronization of estrus. P4 has long been known to bring about synchronization in bovine estrus (LAMOND, 1964; GORDON, 1976), and it can be administered through a variety of routes, including intravaginal devices and ear implants, and even orally. In FTAI protocols, P4 promotes estrus synchronization by supplementing or replacing endogenous P4, thus simulating the action of a corpus luteum (CL) (BARUSELLI et al., 2004).

Commercial formulations containing P4 or progestagen prevented the manifestation of estrus during the treatment period and exerted a negative feedback effect on the endogenous peak of luteinizing hormone (LH), thus blocking the ovulation of the dominant follicle (DF) (SAVIO et al., 1993; STOCK; FORTUNE, 1993). When combined with a source of estrogen at the beginning of the treatment, $\mathrm{P} 4$ promotes regression of the $\mathrm{DF}$, which is dependent on LH for growth. Estrogen also causes atresia of small follicles, whose growth is dependent on follicle stimulating hormone (FSH). As a result, this hormonal combination promotes synchronized emergence of a new wave of follicular growth approximately 3 to 4 days after the initiation of treatment (BARUSELLI et al., 2004).

The use of an injectable P4 source would be an interesting pharmacological strategy to control the estrus cycle, bringing with it a number of potential advantages. Parenteral administration is a very practical method, owing to reduced management demands and greater flexibility when used on a large scale. Using an injectable form would lead to lower P4 production costs by dispensing with the silicone and other materials used in the manufacture of devices and/or implants. A reduction in the risk of health problems associated with intravaginal devices (such as device loss and the occurrence 
of vaginitis and/or vulvovaginitis) has also been cited as a benefit of injectable P4 (MOROTTI et al., 2013a, b). In addition, the injectable P4 would be an interesting alternative to be employed in FTAI protocols, as well as other reproductive biotechnologies.

Very few studies have characterized the effects of injectable P4 in control of the estrus cycle (ULBERG; LINDLEY, 1960; FIKE et al., 1999) and no studies exist, to date, that have investigated its effect on the fertility of cows undergoing FTAI. However, two recent studies investigated the ovarian follicular dynamics of Bos taurus indicus (Nelore) cows in which synchronization of ovulation was brought about by treatment with $\mathrm{P} 4$ via intramuscular (IM) injection versus an intravaginal device (MOROTTI et al., 2013a, b) and similarities were observed between the follicular characteristics in the two groups.

The aim of the present study was to evaluate the pregnancy rate of both lactating and non-lactating Nelore cows undergoing FTAI using an injectable P4 protocol.

\section{Materials and Methods}

Site, animals, and feed management

This study was conducted according to the standards of the Ethics Committee for Animal Experimentation of the State University of Londrina based on Federal Law 11.794 of 08 October 2008.

The experiment was conducted at a farm in South America (latitude $23^{\circ} 24^{\prime} 23^{\prime}$ 'and longitude $57^{\circ} 26^{\prime}$ 4") during the breeding season, from November 2013 to January 2014. The climate is tropical, with an average temperature of $24^{\circ} \mathrm{C}$, and the rainy season extends from November to January.
For this study, 938 multiparous Nelore cows (Bos taurus indicus), aged between 48 and 120 months and with body condition scores (BCS) between 2.5 and 4.0 (on a scale of 0 to 5) (AYRES et al., 2009), were used. During the experimental period, the cows were maintained by continuous grazing on Brachiaria brizantha and Brachiaria humindicula. They were given access to mineralized salt and water ad libitum.

\section{Experimental design and treatments}

The animals were separated into 2 groups: non-lactating cows $(\mathrm{n}=422$; $\mathrm{BCS}=3.0-4.0)$ and lactating cows $(\mathrm{n}=516 ; \mathrm{BCS}=2.5-3.0)$ from 30 to 45 days postpartum. In a random day of estrus (day 0 ), both groups were subjected to the same FTAI hormone protocol, using a source of injectable P4 in an oily vehicle.

The ovulation synchronization protocol was performed with IM injection of $250 \mathrm{mg}$ of injectable P4 (Progessincro, Campos Laboratory Ltda, Londrina, Brazil) in combination with $2 \mathrm{mg}$ of estradiol benzoate (EB) at day 0 (D0). At day 7 (D7), the animals received IM $500 \mu \mathrm{g}$ of cloprostenol (PGF2 $\alpha$; Cyclase ${ }^{\circledR}$ DL, Syntex, Buenos Aires, Argentina). On day 8 (D8), 300 IU equine chorionic gonadotropin (eCG; Novormon ${ }^{\circledR}$, Syntex, Buenos Aires, Argentina) and $1 \mathrm{mg}$ of estradiol benzoate were administered IM (EB; Cipiosyn ${ }^{\circledR}$, Syntex, Buenos Aires, Argentina) and FTAI was performed 36 hours after the D8 application of EB (at day 9; Figure 1). Insemination was performed by the same trained inseminator using conventional semen thawed in a water bath at $35-37^{\circ} \mathrm{C}$ for 30 seconds.

Pregnancy diagnosis was performed 60 days after FTAI by transrectal ultrasonography (model SSD-500, equipped with a $5 \mathrm{MHz}$ linear transducer, Aloka, Tokyo, Japan). 
Figure 1. Schematic representation of the FTAI protocol with injectable progesterone used for synchronization in Nelore cows.

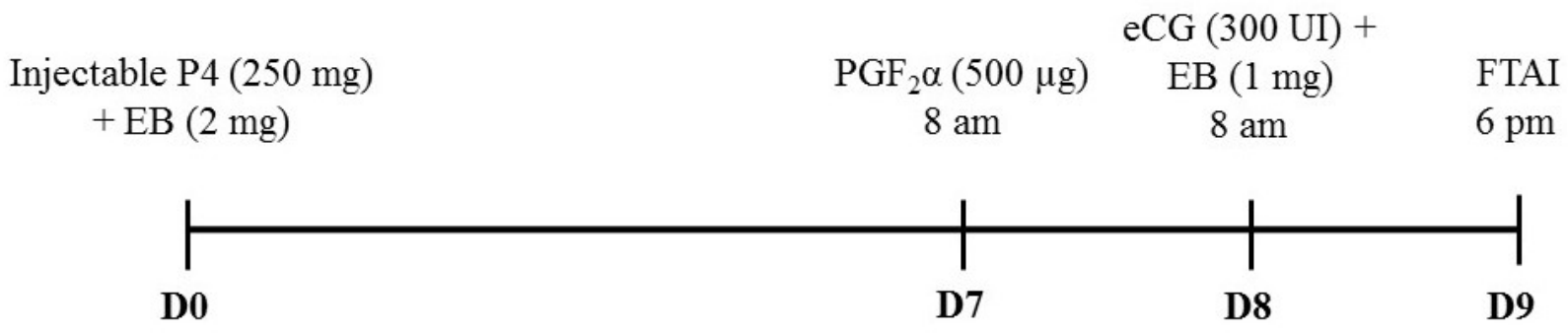

P4 - Progesterone (a single parenteral application on D0).

EB - Estradiol Benzoate.

PGF2 $\alpha$ - Cloprostenol.

eCG - Equine chorionic gonadotropin.

\section{Parameters evaluated and statistical analyses}

The groups were evaluated for pregnancy occurrence 60 days after FTAI was performed. The proportion of lactating and non-lactating pregnant cows was compared using the chi-square test in Minitab - Statistical Analysis Software adopting a significance level of $\mathrm{P}<0.05$.

\section{Results and Discussion}

To our knowledge, this is the first study to evaluate the pregnancy rate for FTAI in Nelore cows using an injectable P4 source (with single application in D0). It may assist the extension of this information base to other studies of control of estrus in cattle, since data on the use of injectable P4 is very limited in the existing literature.

In the present study, it was demonstrated that, out of 422 non-lactating cows, 162 become pregnant within 60 days after FTAI, which equated to a $38.3 \%$ pregnancy rate. In lactating cows $(n=516)$, 166 were pregnant after the hormonal protocol with injectable P4, giving a pregnancy rate of $32.1 \%$. The pregnancy rate in non-lactating cows was higher than that in the lactating group ( $p=0.047$; Table 1) and it is possible that cyclicity and the BCS of the non-lactating females were the main factors contributing to the difference in fertility between the two groups of females synchronized with injectable P4.

Table 1. Pregnancy rates of lactating and non-lactating Nelore cows subjected to FTAI protocol with injectable progesterone.

\begin{tabular}{cccc}
\hline Animal Category & $\begin{array}{c}\text { No. of animals } \\
(\mathbf{n})\end{array}$ & $\begin{array}{c}\text { No. of pregnant animals } \\
(\mathbf{n})\end{array}$ & $\begin{array}{c}\text { Pregnancy rate } \\
(\mathbf{\%})\end{array}$ \\
\hline Non-lactating cows & 422 & 162 & $38.3^{\mathrm{a}}$ \\
Lactating cows & 516 & 166 & $32.1^{\mathrm{b}}$ \\
\hline Total & 938 & 328 & 35.2 \\
\hline
\end{tabular}

Values with different letters in the same column are significantly different $(\mathrm{P}<0.05)$.

The effects of nutrition on the pregnancy rate of Nelore cows subjected to FTAI programs have been shown in other studies. In a study conducted by Ferreira et al. (2013), pregnancy rates of $86.5 \%$
$(\mathrm{BCS} \geq 3 \leq 4)$ and $65.9 \%(\mathrm{BCS} \geq 2.0 \leq 2.5)$ were achieved when comparing two groups of animals with different $\mathrm{BCS}$ ranges. The evaluation of the $\mathrm{BCS}$ is a widely used tool in routine reproductive 
management of cattle, and is a fast and reliable way to assess the nutritional status of the herd. The BCS allows predictions to be made about the response of a group of cattle to a hormonal protocol and, consequently, the expected pregnancy rate (FERREIRA et al., 2013). In this context, data found in the existing literature supports the results of the comparison between our two experimental groups. Non-lactating cows that were cycling showed a higher pregnancy rate, possibly the largest BCS. This result is to be expected since the lactating cows are experiencing a higher nutritional challenge as a consequence of maintaining their calves.

The use of injectable $\mathrm{P} 4$ is an interesting advance for pharmacological estrus control and has a number of advantages over other devices and implants used for $\mathrm{P} 4$ delivery. These include the greater practicality of parenteral administration and increased flexibility when used on a large scale. The use of injectable P4 in a single application facilitates the management of animals and reduces the labor and costs associated with hormone treatment and intravaginal P4 devices (MOROTTI et al., 2013a, b). Such devices are labor intensive, since they require sanitization for adequate storage and re-use. Additionally, the use of injectable P4 eliminates the risk of vulvovaginitis, by removing the need for handling and the potential for intravaginal contamination.

Morotti et al. (2013b) showed some similarities between the ovarian follicular dynamics in Nelore cows subjected to an FTAI protocol using either injectable P4 or an intravaginal device. However, the group receiving the injected $\mathrm{P} 4$ exhibited a lower ovulation rate, possibly because of the metabolism of the injected P4. In the same study, the authors found that the pregnancy rate was also higher in the group of cows synchronized using intravaginal devices $(45.4 \% ; 10 / 22)$ compared to those treated with injectable P4 (18.1\%; 4/22, P = 0.05 ), but the small number of animals used ( $\mathrm{n}=$ 44) limits the usefulness of this study in evaluating pregnancy rates. In the present study, both lactating and non-lactating cows had pregnancy rates higher than those reported by Morotti et al. (2013b). It should also be highlighted that the protocol used in the present study has undergone minor adjustments based on unpublished studies within our research group (MOROTTI et al., 2013a, b).

Ulberg and Lindley (1960) observed that there was no evidence of a marked reduction in fertilization rate using daily $\mathrm{P} 4$ injections. These same researchers also found that the heifers treated with P4 injections in the absence of any other drug showed higher pregnancy rates $(68 \% ; 15 / 22)$ than either the control group that was not treated with hormones $(50 \% ; 11 / 22)$ or a third group of heifers that received injections of $\mathrm{P} 4$ associated with estrogen $(61 \% ; 14 / 23)$.

The present study demonstrated that it is possible to achieve acceptable pregnancy rates using an FTAI protocol with injectable P4. Using a protocol of synchronization and resynchronization of ovulation, Marques et al. (2015) observed a 55\% pregnancy rate in the first FTAI (synchronization) and 80.6\% 30 days after the second FTAI (resynchronization). P4 was administered using a traditional intravaginal device (P4 + EB on D0, removal of the implant + administration of $250 \mu \mathrm{g}$ of PGF $2 \alpha+300 \mathrm{IU}$ eCG + EC D8; insemination of animals 48 hours after removal of the implants) and the study compared heifers, primiparous and multiparous cows lactating. These results were very similar to those observed by Campos et al. (2013), who obtained conception rates ranging from 47 to $54 \%$ after the first FTAI in multiparous Nelore cows.

The results of the present experiment suggest that both the animal category and the BCS have an influence on the pregnancy rate of Nelore cows when using injectable P4. Despite the lower pregnancy rates when compared with conventional P4 protocols (implants and devices), injectable P4 showed promising results, and may be an interesting strategy for FTAI in large-scale livestock production owing to the low handling costs, simplicity of management and reduction in associated labor. 


\section{Conclusion}

This was the first study that used an injectable P4 source as the hormonal basis for large-scale FTAI. It was found that the pregnancy rate of cows subjected to FTAI with injectable P4 was influenced by their lactation status, with the lowest reproductive performance occurring in lactating cows, possibly owing to their lower BCS.

\section{References}

AYRES, H.; FERREIRA, R. M.; TORRES-JÚNIOR, J. R. S.; DEMÉTRIO, C. G. B.; LIMA, C. G.; BARUSELLI, P. S. Validation of body condition score as a predictor of subcutaneous fat in Nelore (Bos indicus) cows. Livestock Science, Amsterdam, v. 123, n. 2-3, p. 175-179, 2009.

BARUSELLI, P. S.; MARQUES, M. O.; CARVALHO, N. A. T.; MADUREIRA, E. H.; CAMPOS FILHO, E. P. Effect of different treatments for timed artificial insemination on the reproductive efficiency in lactating beef cows. Revista Brasileira de Reprodução Animal, Belo Horizonte, v. 26, n. 3, p. 218-221, 2002.

BARUSELLI, P. S.; REIS, E. L.; MARQUES, M. O.; NASSER, L. F.; BÓ, G. A. The use of hormonal treatments to improve reproductive performance of anestrous beef cattle in tropical climates. Animal Reproduction Science, Amsterdam, v. 82-83, p. 479-486, 2004.

CAMPOS, J. T.; MARINHO, L. S. R.; LUNARDELLI, P. A.; MOROTTI, F.; SENEDA, M. M. Resynchronization of estrous cycle with eCG and temporary calf removal in lactating Bos indicus cows. Theriogenology, New York, v. 80 , n. 6 , p. $619-623,2013$

FERREIRA, M. C. N.; MIRANDA, R.; FIGUEIREDO, M. A.; COSTA, O. M.; PALHANO, H. B. Impacto da condição corporal sobre a taxa de prenhez de vacas da raça Nelore sob regime de pasto em programa de inseminação artificial em tempo fixo (IATF). Semina: Ciências Agrárias, Londrina, v. 34, n. 4, p. 1861-1868, 2013.

FIKE, K. E.; WEHRMAN, M. E.; LINDSEY, B. R.; BERGFELD, G.; MELVIN, E. J.; QUINTAL, J. A.; ZANELLA, E. L.; KOJIMA, F. N.; KINDER, J. E. Estrus synchronization of beef cattle with a combination of melengestrol acetate and an injection of progesterone and 17ß-estradiol. Journal of Animal Science, Champaign, v. 77, n. 3, p. 715-723, 1999.
GORDON, I. Controlled breeding in cattle. Part 1: hormone in the regulation of reproduction, oestrus, control, and set time artificial insemination. Journal of Animal Breeding and Genetics, v. 44, n. 6, p. 265-275, 1976.

LAMB, G. C.; DAHLEN, C. R.; LARSON, J. E.; MARQUEZINI, G.; STEVENSON, J. S. Control of the estrous cycle to improve fertility for fixed-time artificial insemination in beef cattle: a review. Journal of Animal Science, Champaign, v. 88, n. 13, p. E181-E192, 2014.

LAMOND, D. R. Synchronization of ovarian cycles in sheep and cattle. Journal of Animal Breeding and Genetics, v. 32, n. 3, p. 269-285, 1964.

MARQUES, M. O.; MOROTTI, F.; SILVA, C. B.; RIBEIRO, M. J.; SILVA, R. C. P.; BARUSELLI, P. S.; SENEDA, M. M. Influence of category - heifers, primiparous and multiparous lactating cows - in a large-scale resynchronization FTAI program. Journal of Veterinary Science, Gwanak-gu, v. 16, n. 3, p. 367-371, 2015.

MOROTTI, F.; CAMPOS, J. T.; OLIVEIRA, E. R.; SENEDA, M. M. Ovarian follicular dynamics of Nelore (Bos indicus) cows subjected to a fixed-time artificial insemination protocol with injectable progesterone. Semina: Ciências Agrárias, Londrina, v. 34, n. 6, p. 3865-3872, 2013a.

MOROTTI, F.; CAMPOS, J. T.; SENEDA, M. M. Fixed-time artificial insemination using injectable progesterone: ovarian follicular dynamics and pregnancy rates of Nelore cows (Bos indicus) with and without a corpus luteum. Semina: Ciências Agrárias, Londrina, v. 34 , n. 6, p. 3873-3882, 2013 b.

SAVIO, J. D.; TATCHER, W. W.; BADINGA, L.; DE LA SOTA, R. L.; WOLFENSON, D. Regulation of dominant follicle turnover during the oestrous cycle in cows. Journal of Reproduction and Fertility, v. 97, n. 1, p. 197-203, 1993.

STOCK, A. E.; FORTUNE, J. E. Ovarian follicular dominance in cattle: relationship between prolonged growth and the ovulatory follicle and endocrine parameters. Endocrinology, Washington, v. 132, n. 3, p. 1108-1114, 1993.

ULBERG, L. C.; LINDLEY, C. E. Use of progesterone and estrogen in the control of reproductive activities in beef cattle. Journal of Animal Science, Champaign, v. 19, n. 4, p. 1132-1142, 1960. 